\title{
ESTÁGIOS CURRICULARES 2000/2001
}

Os estágios da licenciatura em Gestão e Desenvolvimento Social têm contribuído para uma crescente aproximação da Universidade e dos seus licenciandos com o meio organizacional e empresarial.

Tratando-se de estágios curriculares, cabe à Universidade a condução e gestão dos mesmos, no que concerne à sua preparação, acompanhamento e avaliação. Assim sendo, existe um regulamento que é publicado anualmente no Guia do Estudante, onde se encontram definidas as regras e os procedimentos a ter em atenção no que concerne à preparação e acompanhamento dos mesmos.

No fluxograma seguinte, apresentamos as várias etapas do processo de preparação, desde o contacto inicial com as organizações até à atribuição definitiva dos respectivos lugares de estágio aos licenciandos.

\section{Figura 1}

\section{PREPARAÇÃO DOS ESTÁGIOS CURRICULARES / FLUXOGRAMA DO PROCESSO}

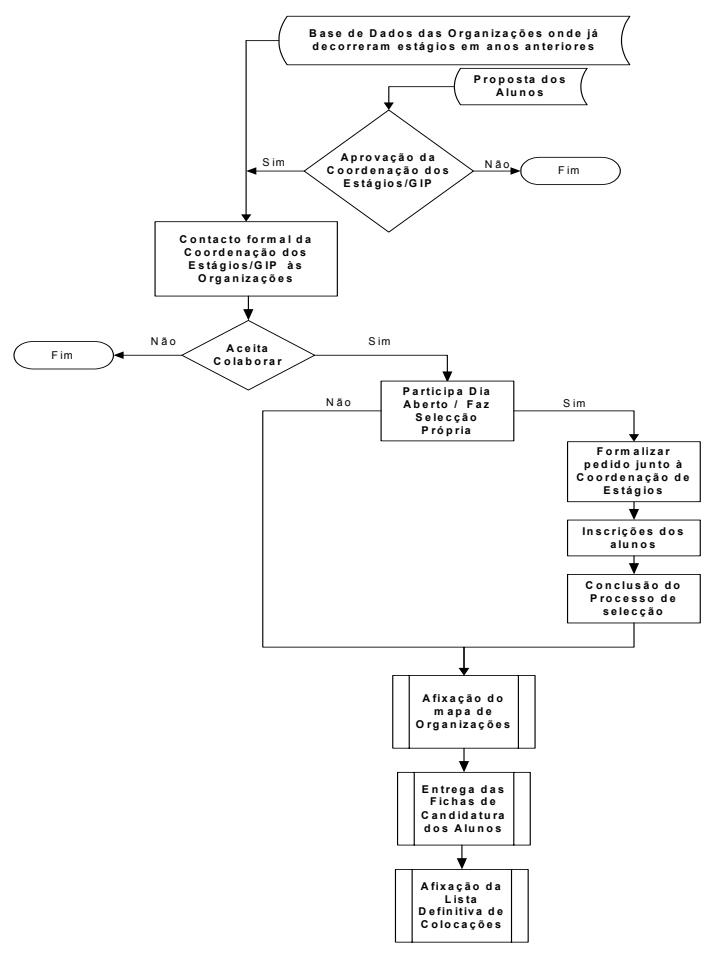


A realização deste estágio, no último ano lectivo da licenciatura, tem oferecido aos nossos alunos uma "primeira" experiência, o mais real e vivida possível, do mercado de trabalho. Esta experiência tem-se revelado útil para a apreensão das suas principais características, em sectores de actividade diversificados, que vão desde a Banca e Serviços até à Logística e à Indústria.

Embora não se perfile a empregabilidade, como objectivo central do estágio curricular, temos verificado que o número de alunos que permanece a trabalhar, no local de estágio, para além do período definido para o mesmo, tem vindo a aumentar (em 2000/2001, a percentagem de alunos que permaneceu foi de $44 \%$ ).

Por outro lado, os estágios curriculares constituem-se também, cada vez mais, como uma alternativa aos tradicionais processos de recrutamento (anúncios em revistas e jornais) encetados, no passado, pelas organizações. Dificilmente encontramos, hoje, uma organização que não assente o seu processo de recrutamento numa bolsa existente de candidatos que já tiveram alguma relação com a própria organização. Os estágios, nesta óptica, constituem um momento de investimento recíproco, cujos resultados nem sempre se manifestam de forma imediata.

A leitura destes e de outros sinais do mercado e a troca de informações com alguns dos nossos parceiros, neste processo, tem-nos reforçado a convicção de que a busca de qualificações já é e será prioritariamente feita junto das entidades formadoras. Esta metodologia comporta um conjunto de vantagens que podemos traduzir, grosso modo, em duas: rapidez do processo de recrutamento e selecção e maior probabilidade de fazer o "best fit" dos perfis a analisar com as necessidades de recrutamento.

Tendo consciência desta realidade e de que o cumprimento dopapel de cada organização passa por ter em especial atenção às necessidades das outras, a coordenação dos estágios curriculares considerou oportuno realizar um dia aberto, com a presença de alunos e de representantes de organizações.

No âmbito da preparação dos estágios curriculares de 2000-01, ocorreu, pela primeira vez, a título experimental, a realização do referido evento, durante a manhã do dia 29 de Maio. As organizações que responderam positivamente ao nosso apelo foram: a Associação Industrial da Região de Viseu, a Associação Industrial de Águeda, a firma A. Figueiredo Lopes, a Caja Duero, a Caixa Geral de Depósitos, a Imoleasing e a Visabeira. 
A avaliação que fizemos deste evento com o contributo dos seus participantes - alunos e representantes das organizações citadas - foi francamente positiva.

Da lista de organizações que connosco colaboraram nos estágios curriculares do ano lectivo 2000-01, para além das organizações que participaram no dia aberto e que, como tal, puderam conduzir um processo de selecção próprio $^{1}$ foram ainda seleccionadas mais 27 organizações.

No total, estas 34 organizações disponibilizaram 44 lugares de estágio que se distribuem pelos seguintes sectores de actividade:

\section{Figura 2 \\ DISTRIBUIÇÃO DOS LUGARES DE ESTÁGIO POR SECTORES DE ACTIVIDADE}

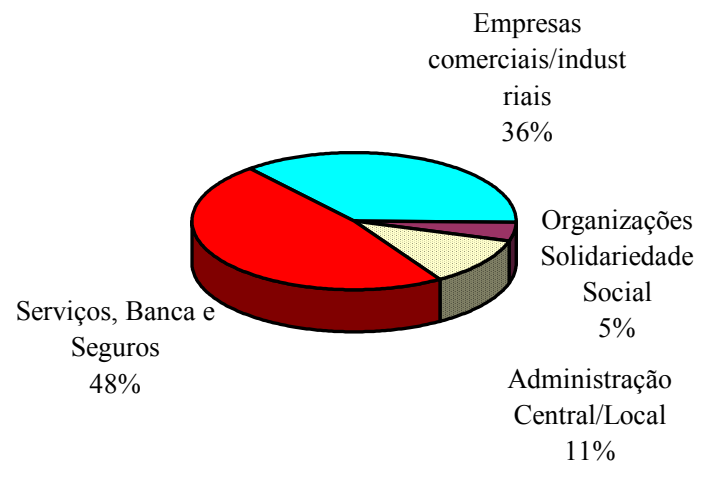

A estes 44 locais de estágio concorreram 29 alunos, dos quais $4 \mathrm{em}$ regime de trabalhador-estudante.

A distribuição dos 29 estagiários pelos locais de estágio encontra-se representada, por sectores de actividade, no gráfico seguinte: 


\section{Figura 3 \\ DISTRIBUIÇÃO DOS ESTAGIÁRIOS POR SECTORES DE ACTIVIDADE}

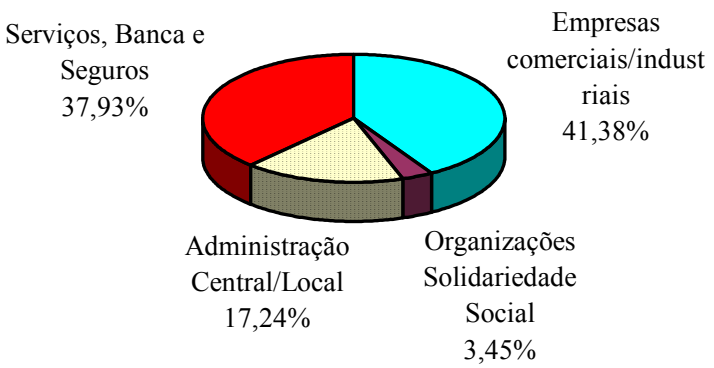

Deve realçar-se que, cada vez mais, o próprio Distrito de Viseu acaba por absorver a maioria dos estagiários representando, neste ano, 86,21\% das colocações. Houve, todavia, 1 estagiário colocado em Guimarães, 2 no Distrito do Porto e 1 em Águeda.

Paulo Castro Ribeiro

NOTA

${ }^{1}$ Ao abrigo do $\mathrm{n}^{\text {o }} 9$ do Regulamento de Estágio da Licenciatura em Gestão e Desenvolvimento Social. Vide fluxograma, página anterior 